Економічні науки: збірник наукових праџь Луцького національного технічного університету. - Серія "Регіональна економіка". - Випуск 15 (59). - Редкол.: відп. ред. д.е.н., професор Л.Л. Ковальська. - Луиьк: ІВВ Луиького НТУ, 2018. - 292 с.

УДК 353.2:330.341

Кривов’ язюк I.В., к.е.н., професор

Кухарук Н.В.

Луцький національний технічний університет

Стрільчук Р.М., к.е.н.

Рівненський державний гуманітарний університет

\title{
ПІДПРИЄМНИЦЬКА ІНІЦІАТИВА В СИСТЕМІ ФАКТОРІВ РОЗВИТКУ ІННОВАЦІЙНОÏ АКТИВНОСТІ В РЕГІОНІ
}

У статті удосконалено наукові положення класифікації факторів розвитку інноваційної активності в регіоні. Вказано на взаємозв'язок інноваційної діяльності, інноваційної активності та підприємницької ініціативи. Запропоновано фактори розвитку інноваційної активності в регіоні поділяти на такі групи: фактори макро- і мезорівня (зовнішні) та мікрорівня (внутрішні). Для кожної групи факторів розвитку інноваційної активності в регіоні розкрито їх взаємозв'язок і визначено субфактори. Узагальнення та систематизація факторів впливу на інноваційну діяльність дозволили виявити, що спільним фактором розвитку на макро- та мікрорівні виступає підприємницька ініціатива.

Ключові слова: підприємницька ініціатива, інноваційна активність, фактори розвитку, регіон.

Kryvovyazyuk I.V., Kuharuk N.V., Strilchuk R.M.

\section{THE SYSTEM OF FACTORS OF DEVELOPMENT OF INNOVATION ACTIVITY IN THE REGION FOR ENTREPRENEURSHIP INITIATIVE}

The development of innovation activity in the region is an important background for increasing the volume of production and sales of innovative products, forming technical and technological base of the region, its investment attractiveness under the conditions of proper regional support through the implementation of targeted regional programs supporting innovation activities, providing various privileges, supporting these processes by regional authorities.

At the current stage of science and practice development, entrepreneurial initiative should be considered as a factor of innovation activity development, that is, its driving force, the reason for its growth, and, at the same time, as one of the main conditions under which this phenomenon occurs. Such duality complicates researching theoretical foundations of the factors of innovation activity 
Економічні науки: збірник наукових праџь Луцького національного технічного університету. - Серія "Регіональна економіка". - Випуск 15 (59). - Редкол.: відп. ред. д.е.н., професор Л.Л. Ковальська. - Луцьк: ІВВ Луцького НТУ, 2018. - 292 с.

development, causing significant debate on determining the range of factors that the entrepreneurial initiative is directly related with.

In order to solve such a problem, it is suggested to divide the factors of the development of innovation activity in the region into groups of macro- and meso levels (as external) and micro-level (internal) factors, which provides a multi-level approach to studying the conditions of regional development.

The main factors of the development of innovation activity at macro level are entrepreneurship development, state support, development of the economic environment and technical and technological potential, which are closely connected to each other. First two factors should be considered in the context of connection with legislative and normative regulation, others - form the natural resource potential.

Among the factors of the regional level or 'meso level' are development of entrepreneurship in the region, regional support of the authorities, investment attractiveness of the region and the technical and technological base of the region. The first two factors should be considered in the context of implementing regional policy, others - as factors of forming innovative potential of the region.

Among factors of micro level it is necessary to allocate organizational and managerial factors, socio-psychological factors, material and technical and intellectual factors. This system of factors forms an entrepreneurial initiative.

The generalization and systematization of the factors of influence on innovation activity has revealed that the entrepreneurial initiative appears in both macro- and micro-level of development that leaves its imprint on the development of entrepreneurship and, in its turn, on innovation activity. At the macro level, the entrepreneurial initiative has an indirect impact on the innovation activity of the enterprise, and at the micro level this impact is direct.

Keywords: entrepreneurial initiative, innovative activity, factors of development, region.

\section{Кривовязюк И.В., Кухарук Н.В., Стрільчук Р.М. \\ ПРЕДПРИНИМАТЕЛЬСКАЯ ИНИЦИАТИВА В СИСТЕМЕ ФАКТОРОВ РАЗВИТИЯ ИННОВАЦИОННОЙ АКТИВНОСТИ В РЕГИОНЕ}

В статье усовершенствованы научные положения классификации факторов развития инновационной активности в регионе. Указано на взаимосвязь инновационной деятельности, инновационной активности и предпринимательской инициативы. Предложено факторы развития инновационной активности в регионе делить на следующие группы: факторы макро- и мезоуровня (внешние) и микроуровня (внутренние). Для каждой группы факторов развития инновационной активности в регионе раскрыто их взаимосвязь и определены субфакторы. Обобщение и систематизация 
Економічні науки: збірник наукових праџь Луцького національного технічного університету. - Серія "Регіональна економіка". - Випуск 15 (59). - Редкол.: відп. ред. д.е.н., професор Л.Л. Ковальська. - Луцьк: ІВВ Луиького НТУ, 2018. - 292 с.

факторов влияния на инновационную деятельность позволили выявить, что общим фактором развития на макро- и микроуровне выступает предпринимательская инициатива.

Ключевые слова: предпринимательская инициатива, инновационная активность, факторы развития, регион.

\section{Постановка проблеми у загальному вигляді та ії} зв'язок 3 важливими науковими й практичними завданнями. Розвиток інноваційної активності в регіоні виступає важливим підгрунттям нарощування обсягів виробництва та реалізації інноваційної продукції, формування техніко-технологічної бази регіону, його інвестиційної привабливості за умов належної регіональної підтримки шляхом реалізації цільових регіональних програм підтримки інноваційної діяльності, надання різноманітних пільг, підтримування цих процесів регіональними органами влади.

Сучасний стан розвитку інноваційної діяльності в Україні та іiї регіонах є вкрай незадовільний, впровадження нових видів діяльності, продукції, технологій тощо $є$ недостатнім для формування повноцінної конкурентоспроможної економіки країни.

За цих обставин особливої уваги потребує створення сприятливих умов для розвитку підприємницької діяльності. А одним із ключових факторів розвитку інноваційної активності в регіоні виступає підприємницька ініціатива, як чинник розвитку власної справи на основі впровадження та реалізації нових ідей та можливостей за рахунок використання необхідних якостей підприємця та володіння певними ресурсами, які при взаємному використанні дають змогу досягнути позитивного економічного ефекту. Це і свідчить про актуальність досліджуваної тематики, спрямованої на формування умов розвитку регіону.

Дослідження виконано в рамках держбюджетної тематики «Механізми створення регіональних студій підприємницької майстерності в умовах децентралізації економіки» (№ 222-17).

Аналіз останніх досліджень і публікацій. Аналіз наукових публікацій ряду вчених, зокрема таких як В. Гриньов [3], В. Зянько [4], О. Кузьмін та Т. Кужда [8], В. Павлов [10], 
Економічні науки: збірник наукових праиь Луиького національного технічного університету. - Серія "Регіональна економіка". - Випуск 15 (59). - Редкол.: відп. ред. д.е.н., професор Л.Л. Ковальська. - Луцьк: ІВВ Луиького НТУ, 2018. - 292 с.

Б. Твисс [12], Л. Федулова [14], А. Шегда [15] показав, що в якості факторів впливу на інноваційну активність обираються ринкові, політико-правові, організаційно-управлінські, фінансовоекономічні, науково-технічні, соціально-психологічні, екологічні, гуманітарні, інформаційні тощо. Н. Бондаренко доповнює фактори, що впливають на інноваційну активність, поділяючи їх залежно від рівня іiі прояву [2]. Проте регіональної специфіки дані автори торкаються лише опосередковано.

До того ж, поза увагою науковців - дослідження як фактор розвитку інноваційної активності в регіоні підприємницької ініціативи, проблематики, започаткованої у роботах $[5 ; 6 ; 7]$.

Цілі статті. Метою дослідження $є$ удосконалення наукових положень встановлення факторів розвитку інноваційної активності в регіоні.

Виклад основного матеріалу. В умовах конкурентоспроможного ринкового середовища підприємству варто використовувати всі можливі шляхи для того, щоб ефективно функціонувати та отримувати дохід. Одним із варіантів не залишатися аутсайдером на ринку $є$ здійснення інноваційної діяльності. Відповідно до чинного законодавства, інноваційна діяльність - це діяльність, що спрямована на використання i комерціалізацію результатів наукових досліджень та розробок і зумовлює випуск на ринок нових конкурентоздатних товарів та послуг [1].

Розвиток інноваційної діяльності характеризує інноваційна активність, яка $є$ iї ступенем інтенсивності [9]. В загальному інноваційна активність $є$ результатом реалізації можливостей підприємницьких структур. Успіх діяльності забезпечується безпосередньо підприємцем, який завдяки ініціативності, розкриваючи свої якості та прагнення, сприяє здійсненню інноваційної діяльності, формуючи відповідний рівень їі інтенсивності. Результатом взаємодії підприємницької ініціативи та інноваційної активності $є$ поява інноваційного продукту.

На сучасному етапі розвитку науки та практики, підприємницьку ініціативу слід розглядати як фактор розвитку 

університету. - Серія "Регіональна економіка". - Випуск 15 (59). - Редкол.: відп. ред. д.е.н., професор Л.Л. Ковальська. - Луиьк: ІВВ Луиького НТУ, 2018. - 292 с.

інноваційної активності, тобто іiі рушійну силу, причину іiі зростання [13], з однієї сторони, та, воднораз, як одну 3 основних умов, при якій відбувається це явище [11]. Така двоїстість ускладнює дослідження теоретичних засад факторів розвитку інноваційної активності, викликаючи значну полеміку щодо визначення кола факторів, 3 якими безпосередньо пов' язана підприємницька ініціатива.

На нашу думку, слід виділити фактори розвитку інноваційної активності зовнішнього та внутрішнього впливу. Пропонуємо зовнішні фактори поділяти на: фактори макрорівня та мезорівня, на які підприємець не може здійснювати вплив. Основними факторами розвитку інноваційної активності на макрорівні можна назвати розвиток підприємництва, державну підтримку, розвиток економічного середовища та технікотехнологічний потенціал, дані складові $€$ тісно пов'язані між собою. Перші два чинника слід розглядати в контексті зв'язку $з$ законодавчо-нормативним регулюванням, а інші формують природно-ресурсний потенціал. Кожний фактор також має свої складові, які на нього впливають. Зовнішні фактори розвитку інноваційної активності та їх взаємозв'язок між собою представлений на рисунку 1. 
Економічні науки: збірник наукових праиь Луиького національного технічного університету. - Серія "Регіональна економіка". - Випуск 15 (59). - Редкол.: відп. ред. д.е.н., професор Л.Л. Ковальська. - Луиьк: ІВВ Луиького НТУ, 2018. - 292 с.

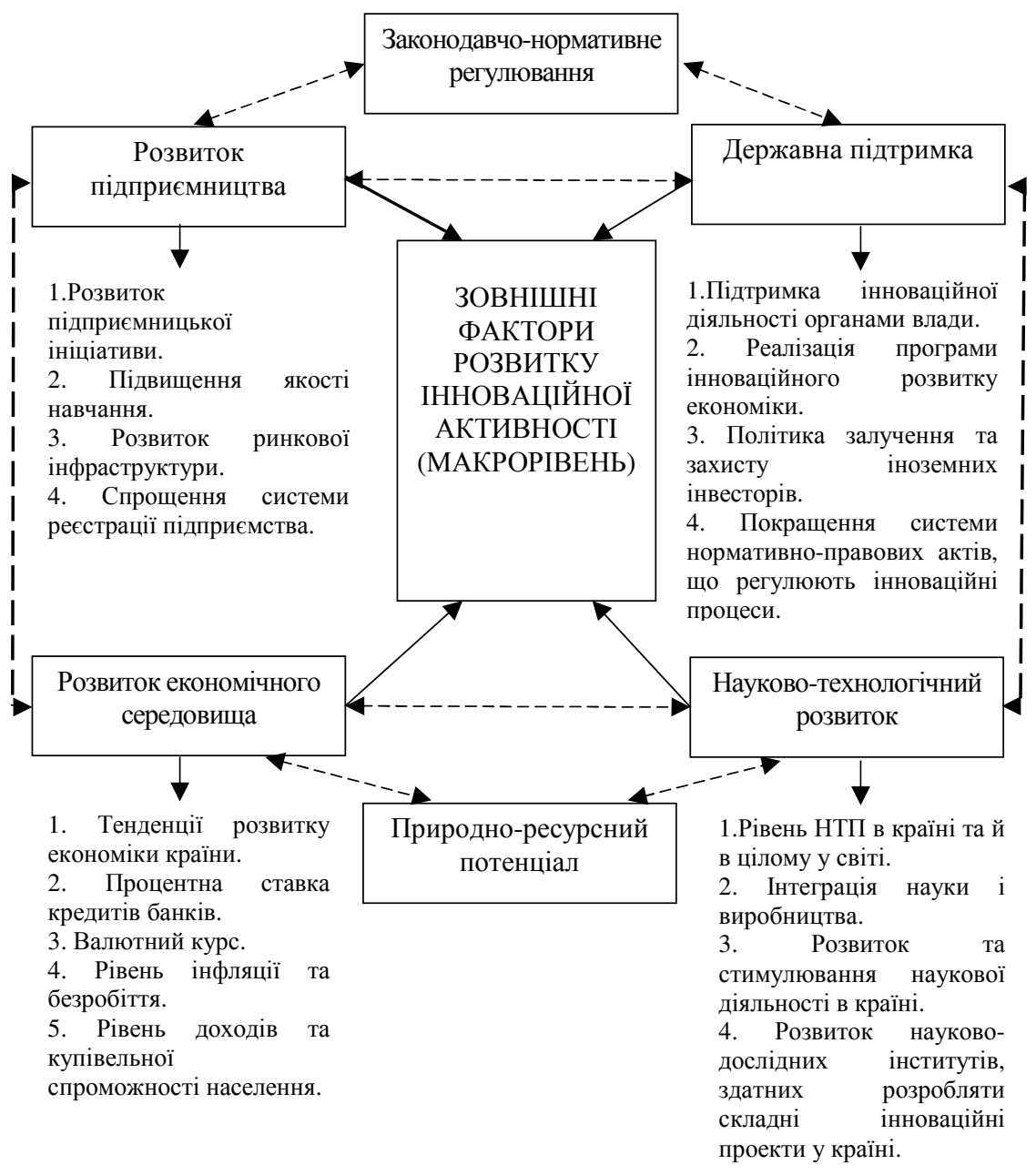

Рис. 1. Зовнішні фактори розвитку інноваційної активності та їх взаємозв' язок на макрорівні (авторська розробка)

До факторів регіонального рівня або мезорівня слід віднести: розвиток підприємництва в регіоні, регіональна підтримка органами влади, інвестиційна привабливість регіону та техніко-технологічна база регіону. Зовнішні фактори 
Економічні науки: збірник наукових праџь Луцького національного технічного університету. - Серія "Регіональна економіка". - Випуск 15 (59). - Редкол.: відп. ред. д.е.н., професор Л.Л. Ковальська. - Луиьк: ІВВ Луиького НТУ, 2018. - 292 с.

розвитку інноваційної активності та їх взаємозв’язок на мезорівні відображено на рисунку 2.

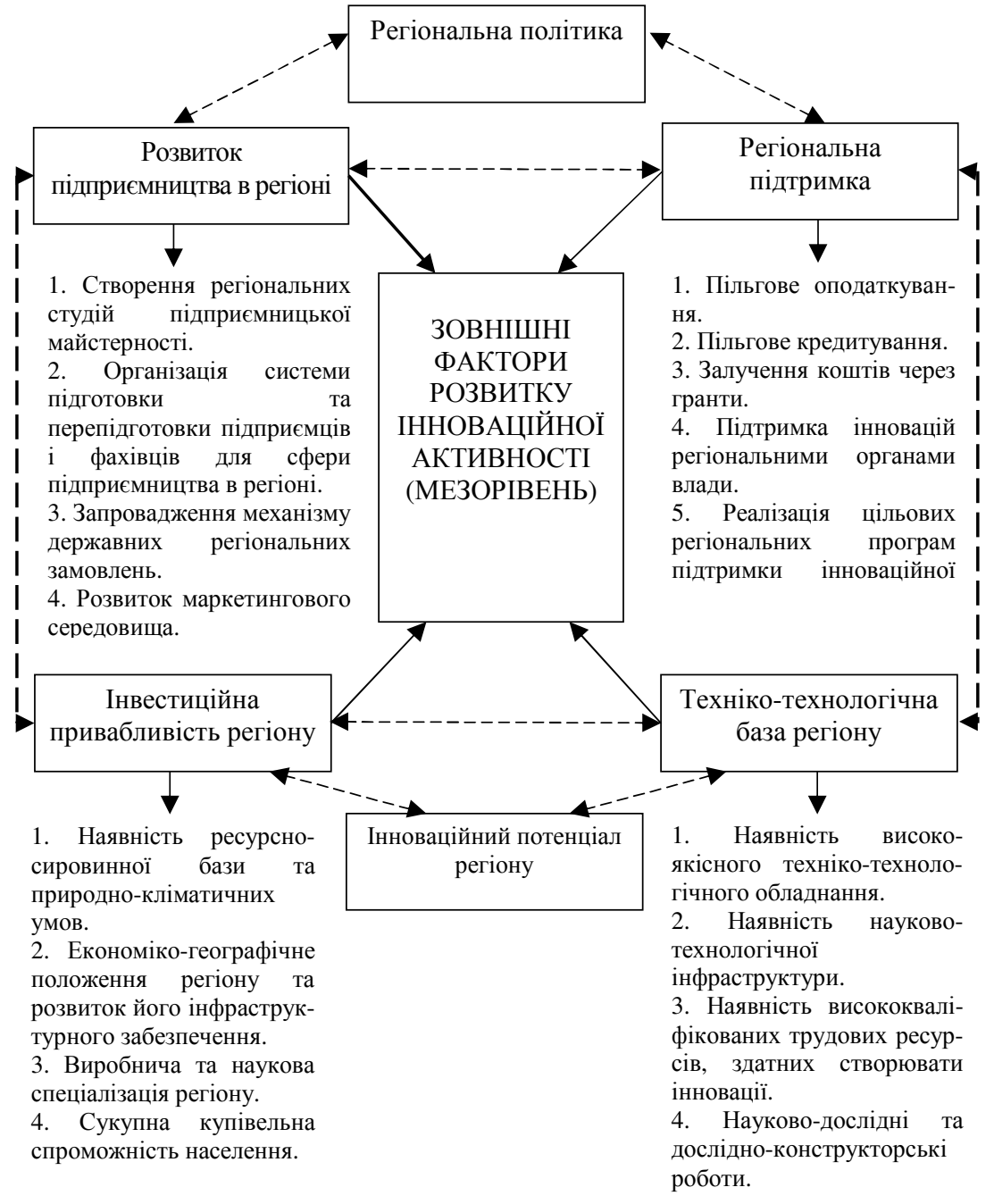

\section{Рис. 2. Зовнішні фактори розвитку інноваційної активності та їх взаємозв'язок на мезорівні (авторська розробка)}


Економічні науки: збірник наукових праџь Луцького національного технічного університету. - Серія "Регіональна економіка". - Випуск 15 (59). - Редкол.: відп. ред. д.е.н., професор Л.Л. Ковальська. - Луцьк: ІВВ Луцького НТУ, 2018. - 292 с.

Внутрішні фактори розвитку інноваційної активності - це безпосередньо ті фактори, на які підприємство має вплив. Серед факторів мікрорівня варто виділити організаційно-управлінські фактори, соціально-психологічні фактори, матеріально-технічні та інтелектуальні фактори (рис. 3). Така система факторів і формує підприємницьку ініціативу, що i формує підприємництво в цілому і його інноваційну активність.

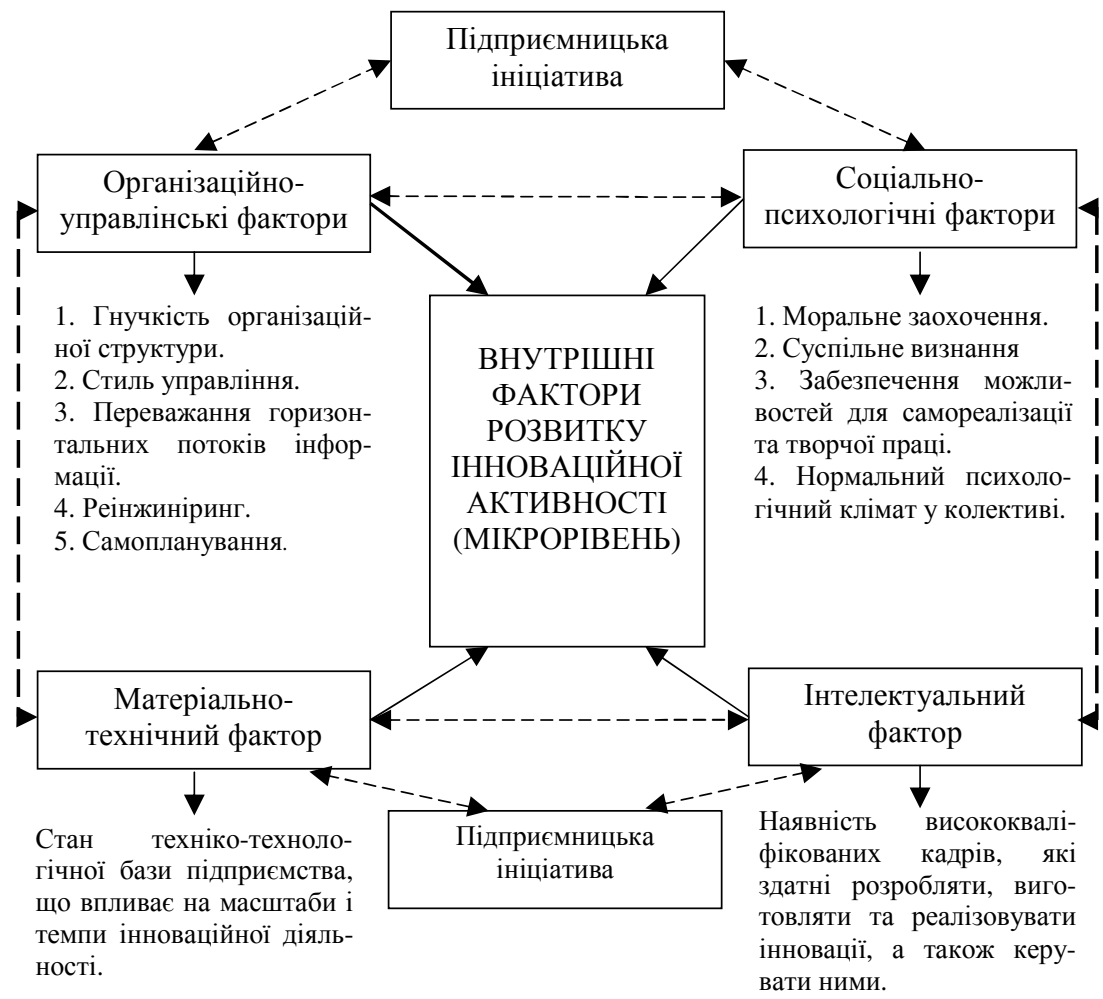

Рис. 3. Внутрішні фактори розвитку інноваційної активності та їх взаємозв' язок на мікрорівні (авторська розробка) 
Економічні науки: збірник наукових праџь Луцького національного технічного університету. - Серія "Регіональна економіка". - Випуск 15 (59). - Редкол.: відп. ред. д.е.н., професор Л.Л. Ковальська. - Луцьк: ІВВ Луцького НТУ, 2018. - 292 с.

Таким чином, розроблені наукові положення класифікації факторів розвитку інноваційної активності в регіоні виступають подальшою основою для вивчення сили та глибини їх впливу на процеси регіонального розвитку.

Висновки. Розвиток інноваційної активності в регіоні виступає важливим підгрунттям нарощування обсягів промислового виробництва та забезпечення конкурентоспроможності продукції. Підприємницьку ініціативу доцільно за таких обставин розглядати як фактор розвитку інноваційної активності, тобто іiі рушійну силу, причину іiі зростання та одну з основних умов, при якій відбувається це явище.

3 метою удосконалення наукових положень класифікації факторів інноваційної активності в регіоні пропонується їх розподіляти на фактори макро- i мезорівня (зовнішні) та мікрорівня (внутрішні), що забезпечує багаторівневий підхід до вивчення умов регіонального розвитку.

До факторів розвитку інноваційної активності на макрорівні входять розвиток підприємництва, державна підтримка, розвиток економічного середовища та технікотехнологічний потенціал. Перші два чинника слід розглядати в контексті зв'язку з законодавчо-нормативним регулюванням, інші - формують природно-ресурсний потенціал.

До факторів регіонального рівня або мезорівня слід віднести розвиток підприємництва в регіоні, регіональну підтримку органів влади, інвестиційну привабливість регіону та техніко-технологічну базу регіону. Перші два фактори слід розглядати в контексті реалізації регіональної політики, інші як фактори формування інноваційного потенціалу регіону.

Фактори мікрорівня розподілено на організаційноуправлінські, соціально-психологічні, матеріально-технічні та інтелектуальні фактори. Така система факторів i формує підприємницьку ініціативу.

Узагальнення та систематизація факторів впливу на інноваційну діяльність дозволили виявити, що спільним фактором розвитку на макро- та мікрорівні виступає 
Економічні науки: збірник наукових праџь Луцького національного технічного університету. - Серія "Регіональна економіка". - Випуск 15 (59). - Редкол.: відп. ред. д.е.н., професор Л.Л. Ковальська. - Луиьк: ІВВ Луиького НТУ, 2018. - 292 с.

підприємницька ініціатива, яка залишає свій відбиток на розвитку підприємництва i, в свою чергу, на інноваційній активності. На макрорівні підприємницька ініціатива здійснює непрямий вплив на інноваційну активність підприємства, а на мікрорівні цей вплив є прямим.

Необхідність підвищення результатів економіки в регіоні iз врахуванням факторів формування інноваційної активності вимагає відповідного методичного забезпечення. Це допомагає побачити реальний стан діяльності підприємств і рівень інноваційної діяльності, а також визначити напрями розвитку підприємницької ініціативи і її зв’ язок з інноваціями.

1. Закон України «Про інноваційну діяльність» (Відомості Верховної Ради України (ВВР), 2002, № 36, ст. 266). - 2002 [Електронний ресурс]. Режим доступу: http://zakon3.rada.gov.ua/laws/show/40-15.

2. Бондаренко Н.М. Напрями підвищення інноваційної активності промислових підприємств / Н.М. Бондаренко [Електронний ресурс]. - 2010. Режим доступу: http://ea.donntu.edu.ua/bitstream/123456789/4031/1/s8_48 _bondarenko.pdf.

3. Гриньов А.В. Інноваційний розвиток промислових підприємств: концепція, методологія, стратегічне управління / А.В. Гриньов. - Х.: ВД «IНЖЕК», 2003. - $308 \mathrm{c}$.

4. Зянько В.В. Інноваційне підприємництво в Україні: проблеми становлення і розвитку: монографія / В.В. Зянько. - Вінниця: УНІВЕРСУМВінниця, 2005. - 263 с.

5. Кривов'язюк I.В. Концепт створення регіональних студій підприємницької майстерності / І.В. Кривов'язюк // Молодий вчений. - 2017. № 3(43). - С. 698-701.

6. Кривов'язюк І.В. Об'єктивні закономірності та теоретичні засади створення регіональних студій підприємницької майстерності в умовах децентралізації економіки [Електронний ресурс] / І.В. Кривов'язюк // Ефективна економіка. - 2017. - №3. - Режим доступу: http://www.economy.nayka.com.ua/?op=1\&z=5480.

7. Кривов'язюк І.В. Теоретичні засади розвитку підприємницького середовища в умовах децентралізації економіки / I.B. Кривов'язюк, Н.В. Кухарук // Економічний форум. - 2017. - № 3. - С. 51-56.

8. Кузьмін О. Фактори інноваційного розвитку підприємств / О. Кузьмін, Т. Кужда [Електронний ресурс]. - 2006. - Режим доступу: http://www.experts.in.ua/baza/analitic/index.php?ELEMENT_ID=11391.

9. Лабунська С.В. Інноваційна діяльність підприємства як фактор ризику та умова зміцнення його економічної безпеки / С.В. Лабунська // 
Економічні науки: збірник наукових праиь Луиького національного технічного університету. - Серія "Регіональна економіка". - Випуск 15 (59). - Редкол.: відп. ред. д.е.н., професор Л.Л. Ковальська. - Луцьк: ІВВ Луцького НТУ, 2018. - 292 с.

Вісник Національного університету «Львівська політехніка». - 2012. - № 725 : Проблеми економіки та управління. - С. 297-304.

10. Павлов В.I. Інноваційний потенціал регіону: діагностика та реалізація: монографія / В.І. Павлов, Ю.М. Корецький. - Луцьк: Надстир'я, 2004. -244 c.

11. Паламарчук Л.С. Словник української мови / Л.С. Паламарчук // Українська мова: енциклопедія. - К.: В. «Укр. енцикл.» ім. М. Бажана, 2004. $612 \mathrm{c}$.

12. Твисс Б. Управление научно-техническими нововведениями / Б. Твисс; [сокр. пер. с англ.; Авт. предисл. науч. ред. К.Ф. Пузыня]. - М.: Экономика, 1989. - 217 с.

13. Управление организацией: Энциклопедический словарь / [под ред. А. Г. Поршнева и др.]. - М.: ИНФРА, 2001. - 812 с.

14. Федулова Л.І. Інноваційний розвиток економіки: модель, система управління, державна політика: монографія / Л.І. Федулова. - К.: Основа, 2005. $552 \mathrm{c}$.

15. Шегда А.В. Менеджмент: підручник / А.В. Шегда. - К.: Знання, 2004. -687 c. 